\title{
Marta Iwaszuk
}

ORCID: 0000-0002-7360-1769

Uniwersytet Wrocławski

\section{Notatki Załmena Gradowskiego w świetle koncepcji świadka moralnego Avishaia Margalita}

Abstrakt: Celem artykułu jest zastosowanie koncepcji świadka moralnego sformułowanej przez Avishaia Margalita w książce The Ethics of Memory do analizy notatek sporządzonych przez Załmena Gradowskiego podczas jego pracy w Sonderkommando w Auschwitz-Birkenau. Aplikacja tej dość ogólnej, ale wyraźnie zarysowanej, koncepcji do konkretnego a jednocześnie trudnego świadectwa pozwoli z jednej strony doprecyzować istotne aspekty kontekstu, jaki kształtuje świadectwo moralne, z drugiej zaś wydzielić i przeanalizować w systematyczny sposób świadectwo moralne Z. Gradowskiego. Artykuł będzie również okazją do sformułowania uwag i pytań dotyczących koncepcji świadka moralnego, których zaadresowanie pozwoliłoby dookreślić paradygmatycznego świadka moralnego na bardziej szczegółowym poziomie, a tym samym zaproponować ustrukturyzowaną analizę niezwykle subtelnego fenomenu, jakim jest każde świadectwo moralne.

Słowa-klucze: świadek moralny, notatki Sonderkommando, Avishai Margalit, Załmen Gradowski

W The Ethics of Memory ${ }^{1}$ Avishai Margalit oprócz wielu rozmaitych rozważań dotyczących pamięci i moralności proponuje niezwykle oryginalną koncepcję świadka moralnego. Jest to świadek, który w obliczu zła i realnego niebezpieczeństwa, jakie to zło stwarza, jest w stanie nieprzerwanie towarzyszyć własnemu zmysłowi moralnemu, a w rezultacie dostarczyć świadectwo z konfrontacji człowieczeństwa z zewnętrznymi siłami zła. Mając świadomość złożoności tego zagadnienia, a także rozmaitych współzależności z zagadnieniami pokrewnymi, koncepcję tę filozof buduje $\mathrm{w}$ formie ram wyznaczających warunki konieczne, jakie musi spełniać paradygmatyczny świadek moralny. Zdaniem Margalita świadek moralny świadczy o przeżywanym bądź obserwowanym złu, a jednocześnie spełnia wiele warunków: 1 . zna bezpośrednio opisywane zło i cierpienia, które ono powoduje; 2. jest narażony na unicestwienie przez zło (zarówno ze wzglę-

\footnotetext{
${ }^{1}$ A. Margalit, The Ethics of Memory, Cambridge MA-London 2004.
} 
du na bezpośredni kontakt z nim, jak i z powodu dawania świadectwa); 3. jego pobudką do dawania świadectwa jest moralność; 4. swoje świadectwo formułuje w nadziei na zaistnienie wspólnoty moralnej, która będzie w stanie je odczytać (mimo iż w jego bezpośrednim zasięgu nie ma takiej wspólnoty); 5. nie pozwala przytłoczyć się jawnej przewadze doświadczanego zła; 6. z prawdy o doświadczanym złu czerpie odwagę; 7. koncentruje się na ujawnianiu zła; 8. rozpoznaje je poprzez pryzmat swojego zmysłu etycznego; 9. przedstawia je w formie adekwatnego zapisu ${ }^{2}$.

W artykule podejmę próbę zastosowania tych ram do konkretnego świadectwa. Pomysł ten niesie dwie trudności. Pierwsza wynika z samej natury filozofii Avishaia Margalita, którą autor ujmuje następująco:

Istnieją dwa rodzaje filozofów: filozofowie „np.” i filozofowie „tzn.”, filozofowie przykładu i filozofowie wyjaśniający. Filozofowie przykładu pokładają zaufanie przede wszystkim w uderzających przykładach, w przeciwieństwie do filozofów wyjaśniających, którzy polegają przede wszystkim na definicjach i zasadach ogólnych. Filozofowie wyjaśniający mogą używać przykładów, lecz ich przykłady są stylizowane i bardziej przypominają to, co następuje po „tzn.”, niż autentyczne przykłady, które następują po „np.”. Z kolei filozofowie przykładu ryzykują tym, że posługują się przykładami jak anegdotami, które nie służą żadnym filozoficznym celom. Zagrożenia towarzyszące obu stylom są jasne i niemal nieuniknione. Jednak jestem przekonany, że styl w filozofii się liczy. Gdy przykłady są trafne, stanowią nie tylko ilustracje dydaktyczne, lecz iluminacje. Gdy definicje są dobre, stają się wyjaśnieniami, a nie jedynie założeniami. Choć dostrzegam zalety obu stylów, to jednak za sprawą mego usposobienia, ale też z przekonania, podpisuję się pod filozofią przykładu ${ }^{3}$.

Choć Margalit uważa się bardziej za filozofa przykładu niż filozofa wyjaśniającego, to sposób, w jaki ilustruje swoje spostrzeżenia, jest fragmentaryczny: jeśli przytacza przykład, odnosi się on przede wszystkim do jednej z cech świadka moralnego. W rezultacie koncepcja ta ma formę kolażu przykładów ilustrujących konieczne warunki, jakie musi spełniać świadek moralny. Choć taka konstrukcja daje pewne wyobrażenie na temat przedstawianej kategorii świadka, to nie dostarcza systematycznej analizy koncepcji na podstawie jednego konkretnego przykładu. Jest to o tyle kłopotliwe, że w rzeczywistości opisany przez Margalita świadek jest zawsze pojedynczą osobą. Taka całościowa analiza wybranego przykładu byłaby też niezwykle pomocnym punktem odniesienia przeprowadzanej przeze mnie analizy notatek Załmena Gradowskiego.

Inna trudność wynika z natury świadectwa, jakie wybrałam do tej analizy, jest to bowiem świadectwo, które powstało w latach 1943-1944 w krematoriach Birkenau i zostało sporządzone przez jednego z członków Sonderkommando — Za-

${ }^{2}$ Nieco inne rozumienie świadka moralnego proponuje Aleida Assmann, por. eadem, Cztery podstawowe typy czynności składania świadectwa, „Wrocławski Rocznik Historii Mówionej” 2018, wydanie specjalne, s. 175-191.

${ }^{3}$ A. Margalit, Preface, [w:] idem, The Ethics of Memory, s. IX. Fragmenty The Ethics of Memory podaję w przekładzie K. Liszki. 
łmena Gradowskiego. Szczególne okoliczności powstania tego świadectwa czynią notatki Gradowskiego podwójnie trudną lekturą: ze względu na zawarty w nich opis bezlitosnego okrucieństwa, a także z powodu braku podobnego doświadczenia po stronie czytelnika. I choć Gradowski dołożył wszelkich starań, aby pomóc czytelnikowi w tej niełatwej lekturze, jego notatki pozostają wymagającym materiałem do badań. Trudność tego świadectwa zawiera się przede wszystkim w tym, co ono przedstawia - masowe mordy i ich wpływ na jednostkę, która nie mogła im zapobiec. Istotnym kontekstem jego odczytania jest równie niełatwa biografia Gradowskiego, której podsumowanie przytaczam na podstawie danych zebranych przez Igora Bartosika ${ }^{4}$.

Załmen Gradowski urodził się w Suwałkach w 1908 lub 1909 roku. Jego ojciec Szmul był kupcem i aktywnym członkiem żydowskiej społeczności, a matka Sara zajmowała się domem i szóstką dzieci: Załmenem, Mojszem, Awromem-Eberem, Fajgele, Libą i Ester-Rochl. Załmen aktywnie uczestniczył w życiu zarówno religijnym, jak i społecznym: uczęszczał do jesziwy w Łomży i przynależał do ruchu Sława Młodzieży Suwałk. Otrzymał ogólne wykształcenie, a jego zainteresowania ogniskowały się wokół zagadnień filologicznych — języka i literatury. Tuż przed wybuchem wojny Załmen ożenił się z Sonią Złotojabłko, pochodzącą z Łunny. Po wybuchu wojny tam właśnie się przeprowadzili, mając na względzie przynależność Łunny do sowieckiej strony konfliktu. Siły Osi 22 lipca 1941 roku zaatakowały Związek Radziecki i już po trzech dniach Wermacht zajął Łunnę. Przez rok Załmen z żoną i jej rodziną żyli w trudnych, ale przewidywalnych warunkach getta. Czas umiarkowanej stabilizacji zakończył się 2 listopada 1942 roku wraz z decyzją o deportacji Żydów z Łunny do obozu przejściowego w Kiełbasinie. Po ponad miesiącu w obozie przejściowym Załmena wraz z rodziną i pozostałymi deportowanymi przewieziono do obozu w Auschwitz. Niemal cała grupa deportowanych została od razu zamordowana, ocalało jedynie 230 silnych i młodych mężczyzn. Następnego dnia Załmen został wybrany do specjalnego komanda. Przez pierwszych kilka miesięcy prawdopodobnie wykonywał typowe prace Sonderkommando, a zatem zajmował się przenoszeniem ciał z bunkrów do dołów spaleniskowych oraz porządkowaniem komory gazowej, by nie nosiła śladów zbrodni i nie wzbudzała podejrzeń kolejnych grup ofiar. Po kilku miesiącach rola Gradowskiego się zmieniła: stał się odpowiedzialny za ewidencjonowanie więźniów, co umożliwiło mu aktywniejszy udział w konspiracji przez sporządzanie zapisów z przeprowadzanych przez SS zbrodni. Aby uzupełnić pisemną dokumentację, członkowie Sonderkommando zdecydowali się zakopać na obszarze krematoriów zęby ofiar, zapewniając tym samym namacalny dowód zbrodni. Ponadto Załmen aktywnie uczestniczył w rozmaitych formach

${ }^{4}$ I. Bartosik, Zalmen Gradowski - świadek Zagłady, [w:] Z. Gradowski, Znajduję się w sercu piekła. Notatki więźnia Sonderkommando odnalezione w Auschwitz, przeł. M. Ruta, M. Siek, Oświęcim 2017, s. 7-14. 
obozowego ruchu oporu, na przykład szmuglował dobra, które posiadali członkowie Sonderkommando, do innych części obozu, co umożliwiało poprawienie warunków bytu więźniów, a także — dosłownie — ratowanie życia, gdyż dobra te często mogły posłużyć za łapówkę dla SS. Jednak najbardziej stanowczym wyrazem niezgody ze strony Gradowskiego było uczestnictwo w organizacji i przewodzenie jedynemu w historii KL Auschwitz-Birkenau powstaniu więźniów. Heroiczny bunt więźniów, choć doprowadził do zniszczenia Krematorium III w obozie Birkenau, został krwawo stłumiony. Zgodnie ze świadectwem Yaakova Freimarka Gradowski został powieszony dzień po buncie. Jego ciało nosiło ślady okrutnych tortur, a czaszka była połamana ${ }^{5}$. Zarówno z jego notatek, jak i z działań podejmowanych w obozie wyłania się obraz niezwykle spójnej postawy moralnej. Uzasadnienia tak wyjątkowej integralności należy prawdopodobnie szukać w głębokiej religijności Gradowskiego, który, jak to było możliwe, praktykował judaizm. Wedle świadectwa Freimarka ${ }^{6}$ po wykonaniu swoich zadań przy spalaniu zwłok Gradowski zakładał talit i odmawiał kadysz za dusze zamordowanych, dbał również aktywnie o morale Żydowskich więźniów, co w rezultacie pozwoliło na organizację — jedynego w historii Auschwitz-Birkenau — powstania.

Mimo iż zarówno filozofia Avishaia Margalita, jak i zapisy Załmena Gradowskiego są mocno nasycone metafizycznym aspektem ludzkiej kondycji, dla proponowanej analizy problemem węzłowym będzie - nieco prostsze - zagadnienie zaufania. Wybór ten podyktowany jest napięciem między gwałtem na międzyludzkim zaufaniu i nieodłącznie $\mathrm{z}$ nim związanym okrucieństwem opisanym przez Załmena Gradowskiego a ufnością w ponadczasowość etyki i moralności, która według Margalita konstytuuje paradygmatycznego świadka moralnego ${ }^{7}$, a która jednocześnie stanowi podstawę wszystkich zapisów Gradowskiego. Przy tak sformułowanym punkcie odniesienia można przyjrzeć się innym warunkom, które zdaniem filozofa musi spełniać paradygmatyczny świadek moralny.

Pierwszym takim warunkiem jest bezpośrednie zaznajomienie się ze złem, to znaczy posiadanie wiedzy o istocie i oddziaływaniu zła z pierwszej ręki, z własnego doświadczenia. Ten warunek Margalit ilustruje przykładem Anny Achmatowej, który wydaje się ukazywać specyficzne położenie moralnego świadka. W cza-

${ }^{5}$ N. Cohen, Diaries of Sonderkommando, [w:] Anatomy of the Auschwitz Death Camp, red. Y. Gutman, M. Berenbaum, Bloomington 1998, s. 523.

${ }^{6}$ G. Greif, We Wept Without Tears: Testimonies of the Jewish Sonderkommando from Auschwitz, New Heaven 2005, s. 361.

${ }^{7}$ Ponadczasowość etyki i moralności wraz z komponentem trzeźwej ufności Margalit opisuje następująco: „Nadzieja, którą przypisuję świadkowi moralnemu, jest raczej wyważona: jest to nadzieja, że w innym miejscu i w innym czasie istnieje lub zaistnieje wspólnota moralna, która wysłucha jego świadectwa. [...] W takich okolicznościach [bezpośredniego narażenia na zło M.I.] przekonanie o możliwości zaistnienia wspólnoty moralnej wymaga prawdziwego aktu wiary", A. Margalit, The Ethics of Memory, s. 155, cyt. za: idem, Świadek moralny, przeł. K. Liszka, „Prace Kulturoznawcze" 24, 2020, nr 1, s. 103. 
sie terroru Nikołaja Jeżowa poetka spędziła w więzieniu siedemnaście miesięcy. Któregoś razu, stojąc wśród innych więźniów, została wywołana po imieniu, a kobieta stojąca za nią, rozpoznawszy jej tożsamość, zapytała: „Czy potrafisz to opisać?”, na co Achmatowa odpowiedziała jej: „Potrafię"8. To krótkie wspomnienie Achmatowej, którym Margalit otwiera swój rozdział poświęcony świadkowi moralnemu, wprowadza jednocześnie dwa ważne warunki: aby pragnąć świadectwa moralnego, potrzeba bezpośredniej znajomości zła poprzez doświadczenie go i cierpienia, jakie powoduje; jednocześnie aby zrealizować pragnienie świadectwa moralnego, potrzebna jest zdolność do uchwycenia i reprezentowania przeżycia skrajnego, jakie wywołuje zdominowanie przez zło 9 .

Pierwszy warunek, a zatem bezpośrednia znajomość krzywdy wyrządzanej przez zło, jest w przypadku świadectwa Załmena Gradowskiego całkowicie spełniony. Równocześnie bliższa analiza jego notatek, szczególnie fragmentów opisujących przybycie do obozu, wskazuje, jak bardzo ogólna jest zastosowana przez Margalita kategoria zła i wywoływanego przez nie cierpienia. Notatki Gradowskiego odkrywają bowiem, jak wiele odcieni i stopni ma bycie ofiarą zła drugiego człowieka: tortury przeżywane w transporcie do obozu okazują się jedynie wstępem do morderstwa całej rodziny Załmena. Kiedy zaś wydaje się, że nic gorszego nie może go już spotkać, trafia do Sonderkommando, w którym codziennie asystuje przy masowych mordach Żydów, co — jak sam przyznał — było tak druzgocącym doświadczeniem, że uniemożliwiało mu nawet przeżywanie żałoby po najbliższych ${ }^{10}$. Kolejnym stopniem niszczenia jest przeprowadzanie selekcji pomiędzy członkami Sonderkommando, które z jednej strony miały na celu redukcję załogi komanda, z drugiej zaś uniemożliwienie pozostałym przy życiu zachowania szacunku do siebie (gdyż tu, w przeciwieństwie do mordu popełnionego na ich rodzinach, członkowie Sonderkommando mogli mieć poczucie wpływu na los skazanych). Opis zróżnicowania odcieni upokorzenia, degradacji, manipulacji i tortur można kontynuować na podstawie świadectwa Gradowskiego, nie jest to jednak celem artykułu. Przywołane przykłady dają pewne pojęcie o ogromnym zróżnicowaniu i dużej skali destrukcyjności zła, a jednocześnie wydają się wprowadzać nieznaczną korektę do koncepcji Margalita, która ujmuje zło w sposób

${ }^{8}$ A. Akhmatova, Instead of a Preface, przeł. S. Kunitz, M. Hayward, [w:] Against Forgetting, red. C. Forche, New York 1993, s. 101-102, przeł. — M.I.

${ }^{9}$ Konfrontacja ze złem, będąc spotkaniem z bezsensem, zawsze oznacza wewnętrzne spustoszenie, a często również fizyczne zniszczenie osoby. Jednocześnie największe ryzyko, jak się zdaje, tkwi w doświadczeniu zdominowania przez niszczący obiekt. Margalit wspomina o tym, porównując Achmatową do żony Lota (A. Margalit, The Ethics of Memory, s. 153). Jeśli zaś idzie o Gradowskiego, to echo tego doświadczenia można odnaleźć w miażdżącym poczuciu winy i ostatecznej decyzji, aby wziąć udział w skrajnie ryzykownej rewolcie. Idealny świadek moralny jest więc kimś, kto dostarcza relacji z konfrontacji ze złem również w zakresie, w którym to zło zniszczyło i zdominowało jego samego, tak aby uniknąć rozegrania tego doświadczenia w działaniu, przeżyć i móc nieść świadectwo.

${ }^{10}$ Z. Gradowski, op. cit., s. 76. 
ogólny, a zakreślając ramy paradygmatycznego świadka moralnego, pozostaje niewrażliwa na rozpiętość skali doświadczanego okrucieństwa ${ }^{11}$.

Drugi warunek wynika z pierwszego i definiuje świadka moralnego jako kogoś, kto jest w niebezpieczeństwie stania się ofiarą tegoż zła, a także naraża się na niebezpieczeństwo, sporządzając swoje świadectwo. Jak zauważa filozof, nie sposób być świadkiem moralnym, będąc jedynie obserwatorem, konieczne jest uczestniczenie $\mathrm{w}$ wydarzeniu, a tym samym przyjęcie na siebie ryzyka wynikającego z przeciwstawienia się złu przez zachowanie swojego - opozycyjnego wobec zła - stanowiska oraz podjęcie próby dokumentacji tego zła:

Świadek moralny powinien ponosić osobiste ryzyko niezależnie od tego, czy to jego samego dotknęło cierpienie wynikające ze zła, czy też je obserwuje. Całkowicie bezpieczny świadek nie jest świadkiem moralnym. Mowa tu o ryzyku dwojakiego rodzaju. Jest to ryzyko przynależności do kategorii ludzi, w których zło zostało wymierzone, lecz jest to również ryzyko wynikające $\mathrm{z}$ dokumentowania i rejestrowania tego, co się wydarzyło, po to, by można było tych świadectw użyć w przyszłości. Możemy zatem mówić o ryzyku bycia ofiarą i o ryzyku bycia świadkiem ${ }^{12}$.

Ten kontekst jest szczególnie ważny dla świadectwa Załmena Gradowskiego. Członkowie Sonderkommando podejmowali wiele różnorodnych prób przeciwstawienia się szaleństwu masowych mordów przeprowadzanych w komorach gazowych Birkenau. Początkowo, nie mogąc otwarcie wyrazić sprzeciwu, dokumentowali zbrodnię: przygotowali zapisy morderstw i rozsypywali zęby ofiar w pobliżu krematorium. Jak wiadomo, to również członkowie Sonderkommando sporządzili cztery fotografie dokumentujące proces zagłady: obrazujące drogę nagich kobiet do komory gazowej oraz palenie zagazowanych ciał w dołach spaleniskowych ${ }^{13}$. Równolegle Sonderkommando przygotowywało bunt, który miał doprowadzić do zniszczenia komór gazowych w obozie Birkenau (zwanym od 1943 roku Auschwitz II), a następnie uwolnienia więźniów z obozu macierzystego (Auschwitz I). Brak wsparcia dla tej inicjatywy ze strony obozowego ruchu oporu wraz z trudnym (ale niewątpliwym) faktem, że wśród konspirujących znajdował się donosiciel, doprowadziły do niepowodzenia tego ważnego przedsięwzięcia. Gradowski, rozumiejąc, jak ogromne ryzyko wiąże się w tych okolicznościach $\mathrm{z}$ wybuchem powstania, pisał w swoim ostatnim liście:

ludzie z obozu, część Żydów, Rosjan i Polaków, wszelkimi środkami nas powstrzymywali i zmuszali, abyśmy odłożyli termin naszej rewolty. Dzień ten jest bliski. Może dziś, może jutro. Piszę

11 Pominięcie stopniowalności i skalowalności okrucieństwa w rozdziale poświęconym świadkowi moralnemu wydaje się zaskakujące, gdyż w znacznej mierze określa położenie i zadanie tej kategorii świadka. Brak ten wydaje się tym dotkliwszy, że zarówno w pozostałych rozdziałach The Ethics of Memory, jak i w innych książkach autora, takich jak The Decent Society (przeł. N. Goldblum, Cambridge MA-London 1996) czy On Compromise and Rotten Compromises (Princeton-Oxford 2010) problem złożoności, skali i wielu odcieni zła jest obecny.

12 A. Margalit, The Ethics of Memory, s. 150, cyt. za: idem, Świadek moralny, s. 100.

13 G. Didi-Huberman, Obrazy mimo wszystko, przeł. M. Kubiak Ho Chi, Kraków 2012, s. 148 149.

Prace Kulturoznawcze 24, 2020, nr 1

(C) for this edition by CNS 
te słowa w chwili największego zagrożenia i zdenerwowania. Niech przyszłość na podstawie moich zapisków wyda wyrok na nas (nas osądzi) i niech świat zobaczy w nich kroplę, minimum straszliwego, przerażającego świata, w którym żyliśmy ${ }^{14}$.

Załmen Gradowski zdecydował się wziąć udział w jedynym w historii KL Auschwitz-Birkenau powstaniu i wspominany jest jako jeden z jego liderów. Całe jego świadectwo, obejmujące niemal dwa lata pobytu w obozie, podszyte jest zaskoczeniem i niedowierzaniem, że tak potworne okrucieństwo ze strony drugiego człowieka jest możliwe. Bezwzględność oprawców, jaką Gradowski opisuje w swoich notatkach, nie pozostawia wątpliwości co do ryzyka, które ponosił zarówno w związku z doświadczaniem zła, jak i z samym sporządzaniem świadectwa. Jednocześnie rozmaitość podejmowanych przez niego działań, które miały, jak się zdaje, to samo źródło co świadectwo moralne, nasuwa pytanie o to, jaką formę może w ogóle przyjąć świadectwo, co stanie się centralnym zagadnieniem dalszej części niniejszego artykułu.

Znajomość zła poprzez bezpośrednie doświadczenie oraz ryzyko (wynikające $\mathrm{z}$ tego położenia) dla uczestnika i świadka wydają się podlegać naczelnej zasadzie związanej z moralnymi celami świadka moralnego. Ten trzeci, przewodni warunek rezonuje z najbardziej podstawowymi aspektami ludzkiej kondycji i jednocześnie wydaje się definiować świadectwo jako świadectwo moralne, a nie polityczne lub jeszcze inne. W swojej koncepcji Margalit podpowiada, że umotywowanie dawania świadectwa określa właściwie jego charakter i rolę, pokazuje jednak również, że rozmaite motywacje mogą zachodzić na siebie, to jest współistnieć $\mathrm{z}$ sobą, a być może nawet $\mathrm{z}$ siebie nawzajem wynikać ${ }^{15}$. Zamiar moralny niewątpliwie był dla Gradowskiego główną motywacją do pisania, na co wskazują już wstępne akapity jego notatek:

Poświęcone mojej rodzinie spalonej w Auschwitz-Birkenau

Mojej żonie Soni,

Mojej matce Sarze,

Mojej siostrze Esterze-Racheli,

Mojej siostrze Libie,

Mojemu teściowi Rafaelowi,

Mojemu szwagrowi Wolfowi.

[...] Podejdź do mnie, szczęśliwy obywatelu świata, [który mieszkasz w] kraju, gdzie istnieje jeszcze szczęście, spokój [i radość]. Opowiem ci, jak [nowocześni, podli przestępcy] zamienili szczęście narodu w gehennę, a spokój w wieczny smutek, jego radość [zniszczyli na wieczność]. Podejdź do mnie wolny obywatelu świata, [gdzie twoje życie jest] zabezpieczone przez ludzką moralność, a twoja egzystencja [zagwarantowana przez prawo]. Opowiem ci, jak współcześni zbrodniarze i [podli] bandyci podeptali moralność życia i zniszczyli [prawo do egzystencji] ${ }^{16}$.

14 Z. Gradowski, op. cit., s. 157.

15 A. Margalit, The Ethics of Memory, s. 147-151.

16 Z. Gradowski, Wprowadzenie do pierwszego manuskryptu, [w:] idem, op. cit., s. 19. 
Podobnie brzmi wstęp do opisu selekcji wśród członków Sonderkommando będącego częścią drugiego rękopisu:

\section{Drogi czytelniku!}

Tę moją pracę poświęcam towarzyszom, ukochanym braciom, których tak nieoczekiwanie od nas zabrano. Kto wie, dokąd ich zaprowadzono. Mamy złe przeczucia, ponieważ znamy „ich” [Niemców] aż za dobrze.

Poświęcam im tych kilka linijek jako wyraz mojej głębokiej miłości i przywiązania. Drogi czytelniku, jeśli kiedykolwiek będziesz chciał zrozumieć, poznać nasze ,ja”, przemyśl wówczas dobrze te słowa - znajdziesz w nich nasz obraz, a także zrozumiesz, dlaczego byliśmy tacy, a nie inni.

Piszę te wersy również po to, abyś mógł z nich zaczerpnąć [przynajmniej] częściową wiedzę, w jaki sposób zginęły dzieci naszego narodu ${ }^{17}$.

Nie ulega więc wątpliwości, że celem notatek Gradowskiego było zarówno ujawnienie zbrodni, opisanie moralnego ciężaru bycia więźniem obozu Auschwitz-Birkenau, jak i objaśnienie, jak to jest być sprowadzonym — pod groźbą kary śmierci — do roli instrumentu w nazistowskiej fabryce śmierci. Jednocześnie notatki Załmena ilustrują ważny, uwzględniony w rozważaniach Margalita, wątek moralności samego świadka moralnego i kompromisów, do jakich może być zmuszony. Filozof w swojej koncepcji dostrzega złożoność sytuacji świadka moralnego i rozpoznaje, że w warunkach bezpośredniej konfrontacji ze złem, a tym samym realnym niebezpieczeństwem, świadek ów może być zmuszony do trudnych i niejednoznacznych moralnie wyborów:

Paradygmatycznym przykładem świadka moralnego powinien być ktoś o nieposzlakowanej moralności. Jednakże świadkiem moralnym może być też ktoś, kto zawiera pewien kompromis moralny, aby przetrwać, zwłaszcza gdy celem jest przetrwanie w roli świadka. Nie czuję się w pełni zadowolony z przyjęcia takiego stanowiska, ale jest to konieczne ze względu na straszliwe okoliczności, w jaki niektórzy ludzie muszą walczyć o przetrwanie — okoliczności, wobec których w pierwszym rzędzie potrzebujemy świadka moralnego ${ }^{18}$.

Ten problem jest oczywiście wyraźnie obecny w świadectwach i wspomnieniach członków Sonderkommando. Jak pokazuje w wywiadach z byłymi członkami Sonderkommando Gideon Greif, tak zwani powiernicy tajemnic (bearers of secrets) byli niechętnie przyjmowani ze swoją wiedzą ${ }^{19}$ i potrzeba było kilku dekad, aby powszechnie oswoić się z myślą, że współczesna forma zła dokonuje zniszczenia nie tylko przez fizyczny atak i przejęcie zasobów, lecz sięga nawet poziomu etycznego przeżywania siebie. Jednocześnie problem przekazywania trudnej i niechcianej wiedzy w świadectwie moralnym wydaje się kluczowy dla zagadnienia świadka moralnego i dlatego wymaga odpowiedzi na pytania: Czy „wspólnota moralna”20 (jako odbiorca świadectwa moralnego) musi być gotowa

17 Z. Gradowski, Znajduję się w sercu piekta..., s. 75.

18 A. Margalit, The Ethics of Memory, s. 162, cyt. za: idem, Świadek moralny, s. 107.

${ }^{19}$ G. Greif, op. cit., s. 72.

${ }^{20}$ A. Margalit, The Ethics of Memory, s. 155. 
na każdą, nawet najgorszą prawdę? Czy brak takiej gotowości uniemożliwia odbiorcom bycie „wspólnotą moralną"21?

Zacytowane wprowadzenia do poszczególnych rozdziałów obydwu manuskryptów zawierają fragmenty spełniające również czwarty warunek dawania świadectwa moralnego, wyrażają bowiem nadzieję na istnienie czytelnika, który znalazłszy zapisane świadectwa, będzie w stanie uchwycić ich moralny wymiar, a tym samym zrozumieć opisane w nim okrucieństwo i podjąć nad nim dalszą refleksję. Jednocześnie Gradowski nie ukrywa, że jednym z jego celów jest dostarczenie dowodów, które pozwolą skazać sprawców masowych mordów dokonanych w KL Auschwitz-Birkenau. Należy jednak podkreślić, że pragnienie to pozostaje $\mathrm{w}$ służbie przewodniego celu moralnego i w tym sensie wydaje się jedną z form jego realizacji. W nadziei Gradowskiego na istnienie „odbiorcy moralnego", czy też jak określa to Margalit — „wspólnoty moralnej"22, jest ponadto spora doza przezorności i zmysłu praktycznego. Można wręcz powiedzieć, że Gradowski nie tylko ma nadzieję na istnienie wspólnoty moralnej, ale walczy o dotarcie do takiej społeczności. Zwrot do znalazcy, poprzedzający pierwszy rękopis, a sporządzony w czterech językach, jest jednym z przejawów takiej walki. Autor ma świadomość, jak różne losy może mieć list, który nadaje, dlatego przewidując, że może on być odnaleziony przez osoby nieznające języka jidysz, kieruje do nich prośbę o poświęcenie uwagi temu dokumentowi ze względu na jego znaczenie historyczne i moralne.

W opisie koncepcji świadka moralnego Margalit wiąże świadectwo moralne z przewagą oprawcy nad świadkiem-ofiarą, łącząc w pośredni sposób tę konfrontację z wymiarem czasu. Ten piąty warunek wskazuje, że świadek moralny musi wykazać się heroizmem w obliczu dysproporcji sił pomiędzy oprawcą a ofiarą, a jednocześnie potrafić odróżnić wizję przyszłości narzucaną przez zło od realnego zasięgu i możliwości oprawcy:

ludzie zniewoleni przez zbrodnicze reżimy, które dążą do unicestwienia moralnej tkanki wspólnoty, zaczynają postrzegać reżim jako niemożliwy do pokonania czy wręcz niezniszczalny, tracąc wiarę w samą możliwość zaistnienia wspólnoty moralnej. Będąc bezsilnym więźniem nazistowskiego obozu koncentracyjnego czy bolszewickiego gułagu, można uwierzyć w to, że tysiącletnia Rzesza i niepowstrzymana niszczycielska siła komunistycznego tryumfu stanowią jedyną możliwą rzeczywistość. Asymetria władzy między ofiarą a sprawcą z każdą chwilą zdaje się potwierdzać niezwyciężalność reżimu. W tak straszliwych warunkach wiara w coś, co w normalnych okolicznościach byłoby raczej rozsądnym przekonaniem - mianowicie w to, że siła zła jest ograniczona i tymczasowa - jest rzeczywiście trudna ${ }^{23}$.

Dla świadka moralnego kwestia czasu jest kluczowa, a istotność czasu wydaje się mieć dla niego dwojaki charakter: bez wątpienia czas trwania jego podległości pod władzę oprawcy przekłada się zarówno na jego wiedzę o złu, jak i ponoszo-

\footnotetext{
${ }^{21}$ Ibidem.

22 Ibidem.

${ }^{23}$ Ibidem, s. 155, cyt. za: A. Margalit, Świadek moralny, s. 103.
} 
ne przez niego ryzyko. Istotnym komponentem zagadnienia czasu w kontekście świadectwa moralnego jest zdolność świadka moralnego do takiej percepcji czasu, która uwzględnia trwałość dobra i zła. Dopiero odróżnienie stałości dobra od tymczasowości zła pozwala w pełni dać świadectwo moralne o doświadczonym okrucieństwie. Gradowski spędził w Auschwitz-Birkenau niemal dwa lata. Znając bieg wydarzeń tamtych czasów, łatwo dostrzec, że wymagany przez Margalita heroizm nie jest jednorazowym aktem, ale stałym zmaganiem się z rzeczywistością, która jest nie do zniesienia i w której myślenie o przyszłości może chwilami być nie tylko trudne, ale wręcz niemożliwe.

Kolejny warunek jest szczególnie ważny, gdyż określa istotę świadka moralnego, wyznaczając mu za cel ukazywanie zła poprzez wyjaśnianie, jak to jest być przedmiotem - często ekstremalnego — zła. Podczas gdy to ogólne stwierdzenie nie budzi większych wątpliwości, jego szczegółowe objaśnienie sprawia pewne kłopoty. Zastrzeżenia wywołuje na przykład rozróżnienie, jakiego dokonuje filozof, gdy twierdzi, że to świadek polityczny opisuje obserwowane fakty zewnętrzne, świadek moralny zaś — przeżycia i rozpoznania etyczne przez nie wywoływane:

Typem idealnym świadka politycznego jest ten, który wierzy, że zgromadzone przezeń dowody winy są jednym z instrumentów prowadzenia wojny. Świadkowie polityczni nie tylko wierzą, że gdzieś kiedyś znowu zaistnieje wspólnota moralna, która zwróci uwagę na ich historię, lecz raczej żywią nadzieję na odegranie aktywnej roli w ujawnieniu owej historii.

Z kolei paradygmatyczny świadek moralny przypisuje wartość własnemu świadectwu bez względu na to, w jaki sposób owo świadectwo może zostać wykorzystane. Świadek polityczny, ze względu na temperament i przygotowanie, może być znacznie lepszym świadkiem całej struktury zła, a nie jedynie jego pojedynczych epizodów, niż świadek moralny. Przez to może być cenniejszym świadkiem w odkrywaniu prawdy faktograficznej. Świadek polityczny może odegrać zacną rolę w zwalczaniu zła wbrew wszelkim przeciwnościom. A jednak pomimo łączących ich cech świadek polityczny jako typ idealny różni się od świadka moralnego i nie powinien być z nim mylony. Obaj zaangażowani są w odkrywanie tego, co zło stara się zakryć. Świadek polityczny może być bardziej skuteczny w ujawnianiu prawdy faktograficznej, w opowiedzeniu, jak było. Świadek moralny potrafi opowiedzieć, jak to odczuwał, a mianowicie jak to jest być narażonym na zło tej miary. Pierwszoosobowa perspektywa w relacjach świadków moralnych ma kluczowe znaczenie dla tego, o czym zaświadczają, podczas gdy świadkowie polityczni mogą, niewiele tracąc, złożyć świadectwo z perspektywy osoby trzeciej ${ }^{24}$.

Zgadzając się w pełni z Margalitem, że relacje z konfrontacji ze $\mathrm{złem}^{25}$, są nam szczególnie potrzebne, jednocześnie uważam za niekonsekwentne rozłączanie faktów zewnętrznych i przeżyć wewnętrznych w myśleniu o tych relacjach. Przeciw takiemu rozdzieleniu przemawiają także notatki Gradowskiego, które dowodzą, że relacja z centrum piekła musi obejmować zarówno fakty historyczne, jak i doświadczenia, a nawet zmiany wewnętrzne nimi wywoływane. Choć może się to wydać zaskakujące, za koniecznością obejmowania przeżyć

24 A. Margalit, Ethics of Memory, s. 167-168, cyt. za: A. Margalit, Świadek moralny, s. 109-110.

${ }^{25}$ A. Margalit, Ethics of Memory, s. 162. 
wewnętrznych i faktów zewnętrznych przemawia nawet zastosowany przez Margalita do zilustrowania świadka moralnego przykład Idy Fink. Cała moc utworów pisarki wydaje się bowiem leżeć właśnie w rozpoznawaniu trudno uchwytnych zewnętrznych (!) mechanizmów ułatwiających zło, które mistrzowsko pokazuje przez pryzmat doświadczeń wewnętrznych. Być może niechęć do akcentowania wymiaru zewnętrznego wynika u filozofa z potrzeby wyraźnego rozdziału między paradygmatycznym świadkiem moralnym a świadkiem, który, postępując moralnie, nie pozostawia jednak po swojej konfrontacji ze złem pisemnego świadectwa z tego przeżycia. Taki rozdział wydaje się jednak nienaturalny, gdyż kategoria moralności nie jest zastrzeżona dla ludzkiego wnętrza, ale dzieje się również jeśli nie przede wszystkim — pomiędzy ludźmi, a to z kolei uzasadnia pytanie o dopuszczalne formy moralnego świadectwa, a raczej o możliwość jego wyrażenia w sferze innej niż reprezentacja artystyczna lub naukowa. Jeśli zaś moralne świadectwo może być wyrażone zarówno przez zapis, jak i przez działanie, wówczas granica między świadkiem moralnym a świadkiem postępującym moralnie się zaciera. Jednocześnie poszerzenie koncepcji świadka moralnego o wypadki, gdy świadectwo wyrażane jest w moralnym postępowaniu (które niewątpliwie może być odczytane z podobną precyzją jak zapis), wydaje się nie tyle rozpuszczać go w koncepcji postępowania moralnego, ile odkrywać — niezwykle istotne, a jednocześnie złożone — warunki i sposoby odpowiedzi moralnej na doświadczane zło.

Za poszerzeniem koncepcji świadka moralnego o sferę działania przemawiają konkretne przykłady świadków moralnych: jeśli przyjrzeć się bliżej wspomnianym już utworom Idy Fink, można w nich rozpoznać nie tylko reprezentację tego, co zewnętrzne, ale wręcz formę działania w zewnętrzności, ponieważ jej twórczość nie tyle prezentuje, ile o d kry w a dla czytelnika ścieżki zła. Jeszcze większą bliskość pomiędzy świadectwem moralnym a działaniem można odnaleźć w notatkach Załmena Gradowskiego. Jego zapisy dowodzą bowiem, że świadectwo moralne polega zarówno na rozumieniu (a więc również reprezentowaniu), jak i na działaniu (egzekwowaniu). Autor ani na moment nie ukrywa, że pragnie, aby jego świadectwo posłużyło ukaraniu winnych, aby stanowiło istotny materiał dla sądu i historii. I trudno myśleć o słusznym gniewie Gradowskiego oraz jego zasadnym dążeniu do sprawiedliwości inaczej niż w kategoriach świadectwa moralnego, dlatego tak niezrozumiały jest opisany przez Margalita związek pomiędzy działaniem a świadkiem politycznym. Aktywny opór wobec zła jest zawsze aktem moralnym, a bywa również działaniem, któremu towarzyszy głębokie intelektualne rozpoznanie (które wydaje się definiować świadka moralnego wyrażającego swoje świadectwo zapisem), nie jest jednak nigdy aktem prymarnie politycznym. Zasadną więc korektą koncepcji Margalita wydaje się przypomnienie, że dopiero cel o charakterze innym niż moralny powinien decydować o zmianie statusu świadectwa na — przykładowo - polityczne. 
Ostatni warunek, jaki można odnaleźć w koncepcji świadka moralnego Margalita, dotyczy posiadania przez niego charyzmatycznej odwagi i zdolności do reprezentowania doświadczenia i rzeczywistości zła. Zdaniem filozofa świadek moralny emanuje charyzmą i odwagą wynikającymi z jego niepowtarzalnego doświadczenia zła. Margalit zakłada więc, że doświadczenie zła jest wydarzeniem zmieniającym osobę. Trudno nie zgodzić się z tym założeniem. Przemawia za nim również lektura notatek Gradowskiego: ukazują one bowiem wyraźnie wpływ doświadczanego i obserwowanego okrucieństwa na autora. Jednocześnie lektura tych notatek wskazuje, że wspomniane przez Margalita charyzma, odwaga i autentyczność wydają się wypływać mniej z doświadczenia zła, a bardziej $\mathrm{z}$ odpowiedzi na to przeżycie $-\mathrm{z}$ dogłębnego rozpoznania moralnego obowiązku W sobie. W tym miejscu powraca kwestia ścisłego związku pomiędzy rozumieniem i działaniem, wydaje się bowiem, że dla Gradowskiego ukrywanie dowodów w postaci zębów ofiar, dokumentacja zbrodni nazistowskich i ich wpływu na niego oraz organizacja i przewodzenie jedynemu powstaniu w obozie Auschwitz-Birkenau były różnymi formami realizacji tego samego obowiązku moralnego. Tym samym przykład Gradowskiego wskazywałby, że bycie moralnym świadkiem i świadkiem moralnym (by użyć rozróżnienia Margalita) ${ }^{26}$ pozostają w bardzo ścisłym związku. Choć jednak moralny świadek nie musi być świadkiem moralnym (a więc składającym swoje świadectwo w formie zapisu, jak chce Margalit), to trudno doprawdy wyobrazić sobie, aby świadek moralny nie był jednocześnie moralnym świadkiem. Wydaje się bowiem, że nawet jeśli świadek moralny zmuszony został do pójścia na jakąś formę moralnego kompromisu, aby przeżyć w obliczu skrajnego zła, to musiał jednocześnie zachować precyzyjny zmysł moralny, aby móc dostarczyć świadectwo moralne ${ }^{27}$.

Złożoności relacjom pomiędzy tymi dwoma rodzajami świadków przydaje wspomniany już przykład Achmatowej. Przywołanie obrazu jej pobytu w więzieniu i krótkiej wymiany zdań z inną więźniarką niesie ładunek wieloznaczności, z której — jak można przypuszczać — autorka zdawała sobie sprawę. Rozpoznanie zła nastąpiło zarówno w poetce, jak i w jej rozmówczyni oraz zrodziło to samo pragnienie świadectwa, powraca zatem pytanie, czy jedyną formą dawania świadectwa moralnego może być zapis. Czy możliwe jest dawanie świadectwa moralnego poza literaturą i sztuką, na przykład w sposobie życia? ${ }^{28}$ Taka reprezentacja

26 Ibidem, s. 149.

${ }^{27}$ Margalit we fragmencie omawiającym tę kwestię pomija całkowicie problem dogłębnego poczucia winy, jakie świadek moralny może przeżywać w wyniku kompromisu moralnego. Jednocześnie kwestia ta wydaje się kluczowa dla możliwości zachowania zmysłu moralnego. Pominięcie tego ważnego wymiaru ludzkiej kondycji czyni proponowany model paradygmatycznego świadka moralnego niepełnym.

${ }^{28}$ A zatem nadal w ramach kultury, którą prof. Stanisław Pietraszko rozumiał jako sposób życia podług wartości, por. idem, Antropologiczne podstawy teorii kultury, [w:] Kultura. Studia teoretyczne i metodologiczne, red. S. Bednarek, Wrocław 2012. 
jest możliwa zarówno do pomyślenia, jak i do odczytania przez odbiorców, choć niewątpliwie komplikuje obraz dawania świadectwa moralnego. Pytanie to jednak stawia wyraźnie sama analiza świadectwa Załmena Gradowskiego, w którym działanie nieustannie przeplata się $\mathrm{z}$ reprezentowaniem.

Zastosowanie definicji świadka moralnego do konkretnego przykładu, to jest świadectwa Gradowskiego, sprowadza ogólną koncepcję filozoficzną do jej konkretnej realizacji w świecie, a tym samym nakłada na nią linearność czasu wraz z wynikającymi z tego ograniczeniami: przestrzeni, możliwych dynamik społecznych czy fizjologii i psychiki jednostki. Konfrontacja ze złem traci w tym zestawieniu wiele ze swego aspektu iluminacji, zamiast której na pierwszy plan wysuwają się nieodżałowane straty, ogromne zniszczenia i przytłaczający obłęd chaosu. Ta zmiana nie ujmuje nic z wartości odkrywania zła, dodaje jednak dość precyzyjny opis jego kosztów, dzięki czemu to, co świadek odkrył poprzez siebie, swój wymiar etyczny i moralny ${ }^{29}$, w wyniku konfrontacji ze złem staje się jednym z elementów bardziej złożonej rzeczywistości, która niewątpliwie dopuszcza przewagę siły nad myślą, a więc chaosu nad porządkiem. Jak nietrudno się domyślić, $\mathrm{w}$ takiej rzeczywistości raport z konfrontacji ze złem, a nawet uchwycenie istoty tego konkretnego zła, jest jedynie częścią, i to nie najważniejszą, towarzyszenia własnej moralności w okolicznościach zagrożenia przez zło ${ }^{30}$. Innymi słowy taka konkretna, a jednocześnie szersza perspektywa zmusza do przyjęcia niewygodnej prawdy, że świadectwo moralne oddziałuje jedynie na siły dobra i w tym znaczeniu jest bezradne wobec zła, którego istotą jest bezsens. O ile więc świadectwo moralne jest w stanie powiększać zasoby dobra, o tyle pozostaje bez wpływu na działania zasilane chaosem. To ważne ograniczenie jest jednym z pierwszych i podstawowych ustaleń Gradowskiego i wydaje się istotnym elementem definiującym pisemne świadectwo moralne.

Zestawienie koncepcji świadectwa moralnego z notatkami Załmena Gradowskiego pozwala również dostrzec pewne braki w teoretycznym ujęciu zła sformułowanym przez Margalita. Nie ma w nim na przykład bezpośrednich rozważań na temat wymiaru czasu, mimo że - jak wskazuje świadectwo Gradowskiego — takie czynniki, jak czas ekspozycji na zło, formy zła, jakie w czasie konfrontacji z złem są ujawnione oraz indywidualne ograniczenia psychofizyczne świadka w danym momencie kształtują sytuację spotkania ze złem. To właśnie te uchwytne i konkretne wskaźniki określają kluczowe warunki świadectwa moralnego:

29 Przymiotnik „moralny” w pojęciu świadka moralnego jest nasycony wymiarem zarówno moralnym, jak i etycznym, por. A. Margalit, The Ethics of Memory, s. 182. Szczegóły rozumienia etyki i moralności Margalita omawia w swojej książce K. Liszka. Zob. K. Liszka, Koncepcja etyki i moralności pamięci Margalita, [w:] eadem, Etyka i pamięć o Zagładzie, Warszawa 2016.

${ }^{30}$ Pisząc o towarzyszeniu własnej moralności, nawiązuję do koncepcji „myślenia dwa-w-jednym”, poszerzam ją jednak o możliwość „towarzyszenia” (myślenia dwa-w-jedynym) podczas działania, por. H. Arendt, Dwa-w-jednym, [w:] eadem, Myślenie, przeł. H. Buczyńska-Garewicz, Warszawa 1991. 
ponoszone przez świadka ryzyko oraz dostępne możliwości poznania przejawów zła i odpowiedzenia na nie. Zaskakujące jest również pominięcie przez filozofa stopni zła, z jakimi przychodzi się podmiotowi skonfrontować, co niewątpliwie nie jest trywialną kwestią dla dawania świadectwa moralnego. Te zastrzeżenia nie powinny jednak przesłonić wartości, jaka płynie z wprowadzenia do refleksji filozoficznej koncepcji świadka moralnego. W namyśle nad moralnością Margalitowi udaje się bowiem wyodrębnić osobisty aspekt etycznej i moralnej aktywności człowieka, który prowadzi do złożenia świadectwa moralnego. Pociąga to za sobą wspomniane pytanie o formy, jakie może przybrać paradygmatyczne świadectwo moralne. Czy musi mieć ono kształt zapisu, artystycznego tworu, który osiądzie w tradycji jako rozpoznawalny element, czy też może przybrać mniej uchwytną formę sposobu życia, kierowanego pragnieniem dania świadectwa moralnego w wyniku osobistego doświadczenia zła?

\section{Zalmen Gradowski's notes in the light of Avishai Margalit's idea of moral witness}

\section{Abstract}

The aim of this paper is to analyze notes written by Zalmen Gradowski during his time as a Sonderkommando in Auschwitz-Birkenau by means of the concept of the moral witness proposed by Avishai Margalit in The Ethics of Memory. Applying this general but well-conceived concept to an individual problematic testimony allows one to refine the matter of context that shapes moral testimony, and at the same time enables a systematic analysis of Gradowski's moral testimony. This paper formulates further observations and questions regarding the concept of the moral witness, thus taking the paradigmatic moral witness to a more complex level, and then creates a template for a structured analysis of the especially subtle phenomenon that is individual moral testimony.

Keywords: moral witness, Sonderkommando notes, Avishai Margalit, Zalmen Gradowski

\section{Bibliografia}

Akhmatova A., Instead of a Preface, przeł. S. Kunitz, M. Hayward, [w:] Against Forgetting, red. C. Forche, New York 1993, s. 101-102.

Arendt H., Dwa-w-jednym, [w:] Myślenie, przeł. H. Buczyńska-Garewicz, Warszawa 1991.

Assmann A., Cztery podstawowe typy czynności składania świadectwa, „Wrocławski Rocznik Historii Mówionej” wyd. specjalne 2018, s. 175-191.

Bartosik I., Zatmen Gradowski - świadek Zagłady, [w:] Z. Gradowski, Znajduję się w sercu piekła. Notatki więźnia Sonderkommando odnalezione w Auschwitz, przeł. M. Ruta, M. Siek, Oświęcim 2017, s. 7-14.

Cohen N., Diaries of Sonderkommando, [w:] Anatomy of the Auschwitz Death Camp, red. Y. Gutman, M. Berenbaum, Bloomington 1998, s. 522-534. 
Didi-Huberman G., Obrazy mimo wszystko, przeł. M. Kubiak Ho Chi, Kraków 2012.

Greif G., We Wept Without Tears. Testimonies of the Jewish Sonderkommando from Auschwitz, New Heaven 2005.

Gradowski Z., Znajduję się w sercu piekła. Notatki więźnia Sonderkommando odnalezione w Auschwitz, przeł. M. Ruta, M. Siek, Oświęcim 2017.

Liszka K., Etyka i pamięć o Zagładzie, Warszawa 2016.

Margalit A., The Decent Society, przeł. N. Goldblum, Cambridge MA-London 1996.

Margalit A., The Ethics of Memory, Cambridge MA-London 2004.

Margalit A., On Compromise and Rotten Compromise, Princeton 2010.

Margalit A., Świadek moralny, przeł. K. Liszka, „Prace Kulturoznawcze” 24, 2020, nr 1, s. 99-117.

Pietraszko S., Kultura. Studia teoretyczne i metodologiczne, red. S. Bednarek, Wrocław 2012.

$$
* * *
$$

Marta Iwaszuk — magister filologii polskiej, kulturoznawstwa i psychologii. Autorka kilku artykułów o analizie kleinowskiej poświęconych badaniu współzależności między świadomym i nieświadomym aspektem semiotycznej aktywności człowieka. Obecnie przygotowuje dysertację doktorską na podstawie notatek Sonderkommanda, w których bada związki pomiędzy umysłem, sztuką i kulturą w ich konfrontacji z ludobójstwem.

marta.iwaszuk@gmail.com 